\title{
Methanolic extract of Urochloa humidicola on in vitro rumen fermentation
}

\author{
Rafaela Scalise Xavier de Freitas(1), Delci de Deus Nepomuceno(1), Elisa Cristina Modesto(1), Tatiana Pires Pereira(1), \\ João Carlos de Carvalho Almeida(1), Leonardo Fiusa de Morais ${ }^{(1)}$, Luiz Gustavo Ribeiro Pereira(2), \\ Fernanda Samarini Machado ${ }^{(2)}$, Mariana Magalhaes Campos $^{(2)}$ and Thierry Ribeiro Tomich ${ }^{(2)}$
}

\begin{abstract}
(1)Universidade Federal Rural do Rio de Janeiro, BR 465, Km 7, CEP 23890-000 Seropédica, RJ, Brazil. E-mail: rafascalise@hotmail.com, delci_ufrrj@yahoo.com.br, ecmodesto@gmail.com, tpireszootec@gmail.com, joaocarlosbq@gmail.com, leonardofiusa@yahoo.com.br (2)Embrapa Gado de Leite, Eugênio do Nascimento, no 610, Dom Bosco, CEP 36038-330 Juiz de Fora, MG, Brazil. E-mail: luiz.gustavo@embrapa.br, fernanda.samarini@embrapa.br, mariana.campos@embrapa.br, thierry.tomich@embrapa.br
\end{abstract}

Abstract - The objective of this work was to evaluate the effect of the addition of the methanolic extract of Urochloa humidicola at four different concentrations $\left(0,75,150\right.$, and $\left.250 \mathrm{~g} \mathrm{~L}^{-1}\right)$ on the in vitro rumen fermentation of Urochloa brizantha. The following variables were evaluated by the in vitro gas production technique: kinetic parameters; rumen degradation of dry matter; and production and concentration of the methane and carbon dioxide gases and of the acetate, propionate, and butyrate short-chain fatty acids. The addition of the methanolic extract reduces the production of gases generated from the degradation of nonfibrous carbohydrates (fraction A) in 9.55, 6.67, and 13.33\%, respectively, at the concentrations of 75,150 , and $250 \mathrm{~g} \mathrm{~L}^{-1}$, compared with the control group, but it negatively affects the degradation of the dry matter of $U$. brizantha at the concentrations of 150 and $250 \mathrm{~g} \mathrm{~L}^{-1}$. The extract shows negative quadratic effect on gas production during 12 and 24 hours of $U$. brizantha incubation. The extract of $U$. humidicola reduces methane production and increases short-chain fatty acid production at the concentrations of 75,150 , and $250 \mathrm{~g} \mathrm{~L}^{-1}$.

Index terms: Urochloa humidicola, methane mitigation, rumen metabolism, secondary plant metabolites.

\section{Extrato metanólico de Urochloa humidicola na fermentação ruminal in vitro}

Resumo - O objetivo deste trabalho foi avaliar o efeito da adição de extrato metanólico de Urochloa humidicola em quatro diferentes concentrações $\left(0,75,150\right.$ e $\left.250 \mathrm{~g} \mathrm{~L}^{-1}\right)$ sobre a fermentação ruminal in vitro de Urochloa brizantha. As seguintes variáveis foram avaliadas pela técnica de produção de gás in vitro: parâmetros cinéticos; degradação ruminal da matéria seca; e produção e concentração dos gases metano e dióxido de carbono e dos ácidos graxos de cadeia curta acetato, propionato e butirato. A inclusão do extrato metanólico reduz a produção de gases oriundos da degradação dos carboidratos não fibrosos (fração A) em 9,55, 6,67 e $13,33 \%$, respectivamente, às concentrações de 75,150 e $250 \mathrm{~g} \mathrm{~L}^{-1}$, em comparação ao grupo controle, mas influencia negativamente a degradação da matéria seca de $U$. brizantha às concentrações de $150 \mathrm{e} 250 \mathrm{~g} \mathrm{~L}^{-1}$. O extrato apresenta efeito quadrático negativo na produção de gás durante 12 e 24 horas de incubação de $U$. brizantha. $\mathrm{O}$ extrato de $U$. humidicola reduz a produção de metano e aumenta a produção de ácidos graxos de cadeia curta às concentrações de 75,150 , e $250 \mathrm{~g} \mathrm{~L}^{-1}$.

Termos para indexação: Urochloa humidicola, mitigação de metano, metabolismo ruminal, metabólitos secundários de plantas.

\section{Introduction}

Rumen is a complex environment where there is an interaction between microorganisms, such as bacteria, protozoa and fungi, and physicochemical conditions. Those microorganisms are responsible for the fermentation process in the rumen, producing microbial protein; short-chain fatty acids (SCFAs) like acetate, propionate, and butyrate; ammonia; carbon dioxide $\left(\mathrm{CO}_{2}\right)$; and methane $\left(\mathrm{CH}_{4}\right)$. However, this process is not considered efficient because the production of $\mathrm{CH}_{4}$ represents a loss of energy and contributes to the greenhouse effect when the gas is eructated by the animal (Castillo-González et al., 2014).

The kinetic parameters of rumen fermentation can be evaluated by the in vitro gas production technique. This technique allows calculating the rate and extent of the fermentation of the feed, as well as evaluating the metabolites generated. 
To improve the efficiency of ruminant production systems, rumen fermentation is manipulated through nutritional strategies, including the use of ionophore antibiotics, lipids, buffers, probiotics, and halogenated compounds in the diet. These additives enable the alteration of the rumen fermentation process and improve the feed efficiency of the animals, while reducing energy loss (Tadesse, 2014).

However, the use of ionophore antibiotics is restricted by the European Union due to the promotion of cross-resistance of pathogenic microorganisms to medicines used to treat human and animal diseases and to consumer pressure for the elimination of nonvegetable xenobiotic agents in animal nutrition (Hao et al., 2014). One of the alternatives to chemical additives (ionophore antibiotics) are plant extracts, as they present secondary or active metabolites, which influence the growth, development, and activity of microorganisms (Tadesse, 2014). Vakili et al. (2013) evaluated cinnamon, garlic, anise, oregano, and pepper extract as a mechanism to manipulate rumen fermentation; however, their use in animal feeding would increase their costs for human consumption.

Some forages have secondary metabolites such as tannins, saponins, terpenes, flavonoids, and alkaloids in their constitution, which are known both for their negative and for their beneficial effects when present in animal feeding (Delgado et al., 2012). Therefore, the use of forage extracts may be an inexpensive mechanism to promote the modulation of rumen fermentation.

Plant extracts are obtained with the use of methanol, ethanol, water, and other solvents (Kim et al., 2012). According to Greathead (2003), some of the effects caused by plant extracts may be linked to the synergistic or additive interactions of their secondary metabolites that act in single or multiple target sites.

Plant extracts obtained with methanol are also constituted by other components of the plant, such as lipids (Manirakiza et al., 2001), which act on the rumen microbiota and, consequently, affect fermentation (Tadesse, 2014). In addition, management practices that increase linoleic acid content in the bovine diet may promote: the increase in conjugated linoleic acid, a proven anticarcinogenic fatty acid in milk that favors the use of those extracts (Khan et al., 2015); an increase in performance; the better use of dietary energy; the reduction of negative impacts on the environment; and the increase in the production of meat products and milk as nutraceutical foods, which can aid in product marketing and valuation.

In Brazil, the main source of feed for cattle are forage grasses, especially Urochloa spp. (Bustamante et al., 2012), which have high mass production and the ability to adapt to different types of soil and climate. Urochloa humidicola produces secondary metabolites, such as saponins, which are associated with its defence system (Wina et al., 2005).

However, the use of plant compounds in ruminant feeding has varying effects. According to Brum et al. (2007), the negative factors are the promotion of diseases and decreases in animal performance. Suharti et al. (2011) observed positive effects on the SCFA profile and a decrease in ruminal $\mathrm{CH}_{4}$ production, when using saponins isolated from Sapindus rarak; this is important given that saponins are also found in U. humidicola (Oliveira et al., 2017).

The objective of this work was to evaluate the effect of the addition of the methanolic extract of $U$. humidicola at four different concentrations $(0,75,150$, and $\left.250 \mathrm{~g} \mathrm{~L}^{-1}\right)$ on the in vitro rumen fermentation of $U$. brizantha.

\section{Materials and Methods}

The experimental procedures were carried out with the approval of the committee on animal research and ethics of Universidade Federal Rural do Rio de Janeiro (UFRRJ) (protocol number 009319/2014).

The experiment was conducted at the laboratory of natural products chemistry of UFRRJ, located in Seropédica, in the state of Rio de Janeiro, and at the multi-use complex for biosciences and livestock sustainability of Embrapa Gado de Leite, in Coronel Pacheco, in the state of Minas Gerais, both in Brazil.

Urochloa humidicola (Rendle) Morrone \& Zuloaga [Syn. Brachiaria humidicola (Rendle) Schweick] was harvested in October, by cutting the plant at $0.05 \mathrm{~m}$ from the soil, at the UFRRJ caprine production sector, located in Seropédica, in the state of Rio de Janeiro $\left(22^{\circ} 46^{\prime} \mathrm{S}, 43^{\circ} 42^{\prime} \mathrm{W}\right.$, at an altitude of $\left.33 \mathrm{~m}\right)$. The climate of the region is of the Aw (tropical humid) type, according to the Köppen-Geiger classification, with dry season from April to September and rainy season from October to March. The soil is classified as a Planossolo Háplico (Santos et al., 2006), i.e., a Haplic 
Albaqualf, being closed for grazing by animals in July and not subjected to fertilization. After harvested, $U$. humidicola was dried under shade for seven days.

After drying, the material was ground into 2-mm particles using the TE 680 Willey mill (Tecnal Equipamentos Científicos para Laboratório, Piracicaba, SP, Brazil), and then $1.063 \mathrm{~kg}$ of the material was put into glass flasks soaked in methanol. The material was filtered through a paper funnel, and the obtained solution was concentrated in a rotary evaporator under low pressure. The residue remaining from the filtration process was placed in an open flask for the complete removal of the solvent through a continuous air flow dryer. The abovementioned steps were repeated until all the plant material was used.

The methanolic extract of $U$. humidicola was subjected to different tests to confirm the presence of secondary metabolites. The assays confirmed the presence of saponins, tannins, non-protein amino acids, carbohydrates, cardiac glycosides, steroids and tripernoids, catechins, and saccharides according to the phytochemical prospecting methodology described by Matos (2009).

After the extraction and confirmation of the presence of secondary metabolites, four different concentrations of $U$. humidicola methanolic extract $(0,75,150$, and $250 \mathrm{~g} \mathrm{~L}^{-1}$ ) were evaluated using the semi-automatic in vitro gas production technique (Mauricio et al., 1999). The methodology was adapted to the use of F57 filters (Ankom Technology, Macedon, NY, USA), and the substrate adopted was Urochloa brizantha (A.Rich.) R.D.Webster [Syn. Brachiaria brizantha (A.Rich.) Stapf] (Table 1) with an average height of $35 \mathrm{~cm}$, which occurred when the canopy reached $95 \%$ interception of photosynthetic active light; the grass was obtained from a pasture at the José Henrique Bruschi experimental field of Embrapa Gado de Leite, located in Coronel Pacheco, in the state of Minas Gerais $\left(21^{\circ} 33^{\prime} \mathrm{S}, 43^{\circ} 16^{\prime} \mathrm{W}\right.$, at an altitude of $\left.410 \mathrm{~m}\right)$. The material was dried at $65^{\circ} \mathrm{C}$ in a forced ventilation oven until constant weight. After dried, it was milled into 2-mm particles using a Willey mill, put into a glass flask, and stocked in a refrigerator.

The F57 filters (Ankom Technology, Macedon, NY, USA) containing the substrate were placed in $50-\mathrm{mL}$ flasks. Then, to each flask were added: $12 \mathrm{~mL}$ culture medium; $4 \mathrm{~mL}$ ruminal fluid obtained from three rumenfistulated Dutch x Zebu cows, maintained under an experimental diet based on corn (Zea mays L.) silage and $U$. brizantha grass for seven days before the fluid was collected; $0.5 \mathrm{~mL}$ of the reducing agent consisting of $\mathrm{Na}_{2} \mathrm{~S} .9 \mathrm{H}_{2} \mathrm{O}+\mathrm{NaOH}$ and distilled water; and $8.95 \mathrm{~mL}$ for each concentration of the methanolic extract of $U$. humidicola $\left(75,150\right.$, and $\left.250 \mathrm{~g} \mathrm{~L}^{-1}\right)$. The flasks containing the substrate with the methanolic extract of $U$. humidicola and the ones containing only solutions without substrate (blank) were sealed with a silicone stopper and an aluminum ring. Incubation was performed in a chamber with controlled temperature at $39^{\circ} \mathrm{C}$.

Gas production was determined using the Druck DPI 705 pressure transducer (GE Measurement \& Control, Billerica, MA, USA), at 2, 4, 6, 8, 10, $12,14,17,20,24,28,34,48,72$, and 96 hours of incubation. For the conversion of the pressure value to volume, the equation developed for local conditions $\mathrm{V}=-0.013 \mathrm{p}^{2}+3.60 \mathrm{p}+0.11$ was used, with $\mathrm{R}^{2}=0.99$ where $\mathrm{V}$ is the total volume of gases and $\mathrm{p}$ is the pressure of the gases inside the fermentation flasks.

The parameters of the fermentation kinetics of $U$. brizantha were estimated by the unicompartmental model proposed by France et al. (1993):

$$
\mathrm{Y}=\mathrm{A}\{1-\exp [(-\mathrm{b}(\mathrm{t}-\mathrm{L})-\mathrm{c}) \times(\sqrt{\mathrm{t}}-\sqrt{\mathrm{L}})]\},
$$

where $\mathrm{Y}$ is the cumulative gas production $(\mathrm{mL}), \mathrm{A}$ is the gas production potential $\left(\mathrm{mL} \mathrm{g}^{-1}\right.$ dry matter), $\mathrm{L}$ is the lag time in hours, and $\mathrm{b}\left(\mathrm{h}^{-1}\right)$ and $\mathrm{c}\left(\mathrm{h}^{-0.5}\right)$ are the constant fractional rates. A fractioned rate $\left(h^{-1}\right)$

Table 1. Chemical-bromatological composition of Urochloa brizantha, Urochloa humidicola, and $U$. humidicola methanol extract (MEUh) in percentage of dry matter.

\begin{tabular}{lccc}
\hline Variable $^{(1)}$ & $\begin{array}{c}\text { Urochloa } \\
\text { brizantha }^{(2)}\end{array}$ & $\begin{array}{c}\text { Urochloa } \\
\text { humidicola }^{(3)}\end{array}$ & MEUh $^{(3)}$ \\
\hline Dry matter (DM) & 91.77 & 89.36 & 81.42 \\
Crude protein (CP) & 12.56 & 5.17 & 10.20 \\
Ether extract (EE) & 1.59 & 1.57 & 35.00 \\
Mineral matter (MM) & 11.58 & 8.14 & 16.14 \\
NFC & 6.24 & 9.53 & 38.52 \\
NDF & 68.03 & 75.59 & 0.14 \\
ADF & 39.86 & 40.77 & 0.18 \\
Lignin & $-(4)$ & 7.19 & 0.17 \\
\hline
\end{tabular}

(1) NFC, non-fibrous carbohydrates; NDF, neutral detergent fiber; and ADF, acid detergent fiber. ${ }^{(2)}$ Results of the chemical-bromatological analysis of U. brizantha (sample 2012613 of Embrapa Gado de Leite, protocol number 20,120,089). ${ }^{(3)}$ Results of the chemical-bromatological analysis of $U$. humidicola and $U$. humidicola methanol extract obtained at the laboratory of animal nutrition of Universidade Federal Rural do Rio de Janeiro. ${ }^{(4)}$ Not analyzed. 
combined with gas production $(\mu)$ was calculated as $\mu=b+c / \sqrt{t}$, where $\mu$ is the gas production rate $\left(\mathrm{mL} \mathrm{g}^{-1}\right.$ fermented dry matter per hour), $\mathrm{c}$ is the fractional rate, and $\mathrm{t}$ is incubation time (hours).

The dry matter degradability (DMD) of $U$. brizantha was analyzed at 12 and 24 hours using the gravimetric method. The results were subjected to the regression analysis. The parameters of the in vitro dry matter effective degradability (DMED) were estimated using the model of France et al. (1993): DMED $=\mathrm{S}_{0} \mathrm{e}^{-\mathrm{kT}}(1-\mathrm{kl}) /\left(\mathrm{S}_{0}+\mathrm{U}_{0}\right)$, where $\mathrm{k}$ is the pass rate; $\mathrm{S}_{0}$ and $\mathrm{U}_{0}$ are the values at time zero of the degradable and non-degradable fractions, respectively; a n d I $=\exp -[(\mathrm{b}+\mathrm{k})(\mathrm{t}-\mathrm{T})+\mathrm{c}(\sqrt{\mathrm{t}}-\sqrt{\mathrm{T}})] \mathrm{dt}$. T h e passage rates of 2,5 , and $8 \%$ per hour were used to estimate the effective ruminal degradability, corresponding to the following levels of feed intake (consumption): low, medium, and high, respectively.

To determine the production of $\mathrm{CH}_{4}$ and $\mathrm{CO}_{2}, 5 \mathrm{~mL}$ of each gas were sampled after pressure measurements at 12 and 24 hours of incubation and stored in vacutainers $(15 \mathrm{~mL})$, and $1 \mathrm{~mL}$ was used for injection in the 7820A gas chromatograph (Agilent Technologies, Santa Clara, CA, USA). The temperature of the oven was maintained at $50^{\circ} \mathrm{C}$ for $4.5 \mathrm{~min}$, which is the required time for the elution of the desired constituents. After the analysis, a heating ramp of 60 to $250^{\circ} \mathrm{C}$ per minute was started. The post-working temperature was maintained at $250^{\circ} \mathrm{C}$ for $2 \mathrm{~min}$.

To determine the amount of SCFAs, $10 \mathrm{~mL}$ fermentation fluid were stored and added to a flask containing $2 \mathrm{~mL} 25 \%$ metaphosphoric acid and then frozen at $-18^{\circ} \mathrm{C}$. Samples were thawed and centrifuged at $14.000 \mathrm{rpm}$ for $10 \mathrm{~min}$ in the Heraeus Megafuge 16R refrigerated centrifuge (Thermo Electron Led GMBH, Osterode, Germany). The supernatant was filtered using the Millex PVDF (Merck KGaA, Darmstadt, Germany) hydrophilic membrane filter with $25 \mathrm{~mm}$ in diameter and $0.45 \mu \mathrm{m}$ in porosity, compatible with the Millipore HVLP02500 Durapore, and then transferred to flasks.

High performance liquid chromatography was performed using the Alliance e2695 liquid chromatograph and the 2998 Photodiode Array detector (Waters Corporation, Milford, MA, USA). The separation system consisted of the ODS-80A reverse-phase column ( $150 \mathrm{~mm} \times 4.6 \mathrm{~mm} \times 5 \mu \mathrm{m})$. The chromatographic conditions were as follows: isocratic mobile phase of $100 \%$ phosphoric acid, $\mathrm{pH} 2.35-$ 2.55 , oven temperature of $30 \pm 5^{\circ} \mathrm{C}$, sample injection volume of $10 \mu \mathrm{L}$, detector of excitation wavelength programmed at $210 \mathrm{~nm}$, and run time of $25 \mathrm{~min}$ for each sample.

The data were analyzed using a linear mixed model considering the inoculum (three donor animals) as the random effect and the treatments $(0,75,150$, and 250 $\mathrm{g} \mathrm{L}^{-1} U$. humidicola methanolic extract) and incubation times (12, 24, 48, and 96 hours) as the fixed effects, with two replicates each. The statistical model used in the ruminal fermentation kinetics was:

$$
Y_{i j k}=\mu+\alpha_{j}+\varepsilon_{(i) j}+\beta_{j}+(\alpha \beta)_{i j}+\omega_{k}+e_{i j k},
$$

where $Y_{\mathrm{ijk}}$ is the dependent variable (gas), $\mu$ is the general mean, $\alpha_{i}$ is the effect of the concentrations of the methanolic extract of $U$. humidicola, $\varepsilon_{(\mathrm{i}) \mathrm{j}}$ is the effect of level i of factor $\alpha$ on replicate $\mathrm{k}$ (error a), $\beta_{\mathrm{j}}$ is the effect of degradation times (12 and 24 hours), $\left(\alpha \beta_{\mathrm{ij}}\right.$ is the effect of the interaction between $U$. humidicola methanolic extract concentrations and degradation times, $\omega_{\mathrm{k}}$ is the block effect (inoculum), and $\mathrm{e}_{\mathrm{ijk}}$ is the experimental error (error $b$ ).

For in vitro DMD, a randomized complete block design was used in a split-plot arrangement. The blocks were represented by the inoculum from three different animals, the plots were the extract concentrations, and the subplots were the incubation times. The statistical model used for DMED was:

$$
\mathrm{Y}_{\mathrm{ijk}}=\mu+\alpha_{\mathrm{j}}+\varepsilon_{(\mathrm{i}) \mathrm{j}}+\delta_{\mathrm{jk}}+\beta_{\mathrm{j}}+(\alpha \beta)_{\mathrm{ij}}+\omega_{\mathrm{k}}+\mathrm{e}_{\mathrm{ijk}},
$$

where $Y_{i j k}$ is the dependent variable (DMED); $\mu$ is the general mean; $\alpha_{\mathrm{i}}$ is the effect of extract concentrations on the studied variable; $\varepsilon_{(\mathrm{i}) \mathrm{j}}$ is the effect of level $\mathrm{i}$ of factor $\alpha$ on replicate $\mathrm{k}$ (error a); $\delta_{\mathrm{ik}}$ is the residual effect of the plots, characterized as a component of error (a); $\beta_{\mathrm{j}}$ is the effect of degradation time (12 and 24 hours) on the studied variable; $(\alpha \beta)_{\mathrm{ij}}$ is the effect of the interaction between extract concentrations and degradation time; $\omega_{\mathrm{k}}$ is the block effect on the studied variable; and $\mathrm{e}_{\mathrm{ijk}}$ is the residual effect of the subplots, characterized as a component of error (b).

Urochloa brizantha was subjected to the chemical analysis (Table 1) to determine the contents of dry matter, crude protein, neutral detergent fiber, acid detergent fiber, ether extract, and lignin in the laboratory of food analysis of Embrapa according to Horwitz \& Latimer Jr. (2005). The data were subjected to the analysis of variance and to polynomial regression using the SAEG software, version 9.1 (SAEG, 2007), 
and the means were compared by the F-test, at 5\% probability.

\section{Results and Discussion}

The addition of the crude methanolic extract of $U$. humidicola increased gas production compared with the control. At the concentration of $150 \mathrm{~g} \mathrm{~L}^{-1}$, a higher gas production was observed in the period of 12 to 48 hours, when it tended to stabilize (Figure 1).

The addition of the $U$. humidicola extract at the concentrations of 75,150 , and $250 \mathrm{~g} \mathrm{~L}^{-1}$ promoted an increase of 80,70 , and $72 \mathrm{~mL}$ in the maximum potential of gas production, respectively, when compared with the control (Table 2).

The highest colonization time required was observed for the control (Table 2). This can be explained by the presence of $39.92 \%$ non-fibrous carbohydrates and of $35 \%$ ether extract (Table 1) in the methanolic extract, which may affect the time of adhesion of the bacteria to the substrate. The degradation of the fiber by ruminal

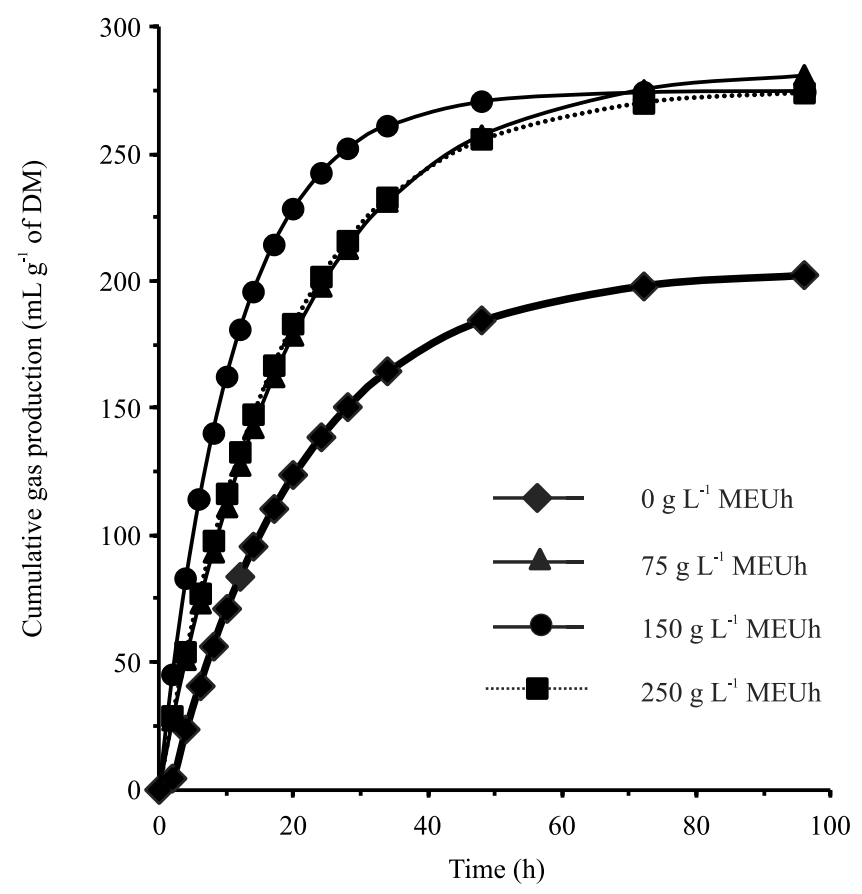

Figure 1. Cumulative gas production of Urochloa brizantha at different concentrations of the crude methanolic extract of Urochloa humidicola (MEUh). microorganisms is a time-dependent process (Seo et al., 2009); in the present study, the addition of extract promoted a decrease in the lag phase compared with the control.

For time to reach half of the asymptote, a decreasing tendency was observed with the addition of the methanolic extract of $U$. humidicola, which may be due to the increase of cellular components and the absence of the cell wall of the extract compared with the control (U. brizantha). The lowest gas production rate was obtained for the concentration of $0 \mathrm{~g} \mathrm{~L}^{-1}$ methanolic extract.

Soluble carbohydrates are related to higher propionate production, while the inverse is observed for fibrous carbohydrates (El-Waziry, 2007). However, due to the increased availability of rapidly fermentable carbohydrates, more gas is produced from the nonfibrous carbohydrates in feeds containing the nutrient, which is consistent with the findings of the present study.

When the extract was added at the concentrations of 75,150 , and $250 \mathrm{~g} \mathrm{~L}^{-1}$, there was an increase in the amount of soluble carbohydrates, which led to an increase of $13.79,10.91$, and $17.57 \%$, respectively, in the values of the soluble fraction of the dry matter of the mixture inoculum $+U$. brizantha. These results are in alignment with those of Guimarães Júnior et al. (2010), who found that high values of soluble fraction indicated a highly degradable material.

Table 2. Estimation of the kinetic parameters ${ }^{(1)}$ of the in vitro gas production of the dry matter of Urochloa brizantha at different concentrations of the methanolic extract of Urochloa humidicola.

\begin{tabular}{lcccc}
\hline $\begin{array}{l}\text { Concentration } \\
\left(\mathrm{g} \mathrm{L}^{-1}\right)\end{array}$ & $\begin{array}{c}\mathrm{A} \\
(\mathrm{mL})\end{array}$ & $\begin{array}{c}\mathrm{L} \\
(\mathrm{min})\end{array}$ & $\begin{array}{c}\mathrm{T} / 2 \\
(\text { hours })\end{array}$ & $\begin{array}{c}\mu \\
\left(\mathrm{mL} \mathrm{h}^{-1}\right)\end{array}$ \\
\hline 0 & 203 & 97 & 21.23 & 0.036 \\
75 & 283 & 0.008 & 12.91 & 0.048 \\
150 & 273 & 0.003 & 11.81 & 0.073 \\
250 & 275 & 0.004 & 13.40 & 0.050 \\
\hline
\end{tabular}

(1) Obtained by the model of France et al. (1993): $\mathrm{Y}=\mathrm{A}\{1-\exp [(-\mathrm{b}(\mathrm{t}-\mathrm{L}) \mathrm{-c})$ $\mathrm{x}(\sqrt{\mathrm{t}}-\sqrt{\mathrm{L}})]\}$, where $\mathrm{A}$ is the maximum potential gas production, $\mathrm{L}$ is the lag phase, $T / 2$ is the time to reach half of the asymptote, and $\mu$ is the fractional rate of gas production. 
The methanolic extract of $U$. humidicola reduced the degradation of the potentially degradable insoluble fraction of dry matter in $69.80 \%$ for the control and in $49.79,25.27$, and $4.18 \%$ for the concentrations of 75,150 , and $250 \mathrm{~g} \mathrm{~L}^{-1}$, respectively (Table 3 ). Grasses present low nutritional value, as they contain high amounts of cellulose and lignin, low concentrations of fermentable sugars, and low-quality proteins (CastilloGonzález et al., 2014), which affects the microbial activity and, consequently, the profile of the products produced by fermentation. For these reasons, the degradation of the potentially degradable insoluble fraction is extremely important for the utilization of cellulose and hemicellulose in grasses.

For the applied concentrations, the highest degradation rate was found for $150 \mathrm{~g} \mathrm{~L}^{-1} \mathrm{U}$. humidicola methanolic extract. The effective rumen degradation was higher at an estimated consumption rate of $2 \%$ per hour $(45.52,38.55,27.57$, and 20.30$)$ for the concentrations of $0,75,150$, and $250 \mathrm{~g} \mathrm{~L}^{-1}$, respectively, compared with the rate of $5 \%$ per hour $(31.80,27.91$, 22.71 , and 19.37$)$ and $8 \%$ per hour $(24.46,23.66,19.33$, and 18.91) for the same periods (Table 3). According to Guimarães Júnior et al. (2010), good quality forage presents degradation rates higher than $2 \%$ per hour, which implies that the $U$. brizantha used in the present

Table 3. Estimations of in vitro rumen degradation of the dry matter of Urochloa brizantha when crude methanolic extract of Urochloa humidicola was added at different concentrations ${ }^{(1)}$.

\begin{tabular}{|c|c|c|c|c|c|c|c|}
\hline \multirow{2}{*}{$\begin{array}{l}\text { Concentration } \\
\left(\mathrm{g} \mathrm{L}^{-1}\right) \\
\end{array}$} & \multicolumn{3}{|c|}{ Parameter } & \multicolumn{3}{|c|}{$\mathrm{DE}$} & \multirow[t]{2}{*}{$\mathrm{R}^{2}$} \\
\hline & $\mathrm{a}(\%)$ & $\mathrm{b}(\%)$ & $\mathrm{c}(\%)$ & 2 & 5 & 8 & \\
\hline 0 & $4.24^{\text {ns }}$ & 69.80 & 0.03 & 47.52 & 31.80 & 24.46 & 0.99 \\
\hline 75 & 13.79 & 49.79 & 0.02 & 38.55 & 27.91 & 23.66 & 0.95 \\
\hline 150 & 10.91 & 25.27 & 0.04 & 27.75 & 22.14 & 19.33 & 0.98 \\
\hline 250 & 17.57 & 4.18 & $0.04^{\mathrm{ns}}$ & 20.30 & 19.37 & 18.91 & 0.63 \\
\hline
\end{tabular}

(1) a, soluble fraction of dry matter; b, potentially degradable insoluble fraction of dry matter; $c$, degradation rate by fermentative action of $b$; DE, effective rumen degradability; $\mathrm{K}$, estimated passage rates of 2,5 , and $8 \%$ per hour, representing animals with low, medium, and high consumption, respectively; and $\mathrm{R}^{2}$, coefficient of determination. The results were obtained through the mean degradation times (12, 24, 48, and 96 hours). *Significant by the analysis of variance for nonlinear regression, at $5 \%$

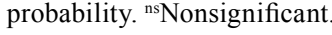

work showed a low degradation rate and was also impaired by the inclusion of the methanolic extract of $U$. humidicola in the diet.

Large amounts of readily available soluble compounds support the highest dry matter disappearance in the rumen between 0 and 24 hours (Patra, 2013). The extract, rich in non-fibrous carbohydrates, when added to the mixture inoculum $+U$. brizantha, promoted an increase in the soluble fraction and a decrease in the potentially degradable insoluble fraction of dry matter, besides hindering the effective rumen degradation.

The extract added in increasing concentrations had a negative quadratic effect on gas production after 12 and 24 hours of incubation (Table 4). A negative linear effect was observed at 12 and 24 hours for DMED and rumen $\mathrm{pH}$ of the medium containing $U$. brizantha.

The suitable $\mathrm{pH}$ for the action of fibrolytic bacteria and rumen protozoa is in the range of 6.2 to 6.8 (Mould \& Ørskov, 1983). At 12 and 24 hours, the $\mathrm{pH}$ values were of 5.73 and 5.43 , respectively, with the addition of $250 \mathrm{~g} \mathrm{~L}^{-1} U$. humidicola extract. Changes in $\mathrm{pH}$ can negatively affect the degradation of the fibrous fraction.

Non-fibrous carbohydrates may promote changes in the physicochemical conditions of the rumen and in the population of microorganisms (Wanapat et al., 2015). Rumen degradation promotes a $\mathrm{pH}$ reduction that may influence the survival of microorganisms, and abrupt changes may interfere in the digestibility of low-quality forages (Castillo-González et al., 2014). In the present study, a moderate correlation was observed between $\mathrm{pH}$ and dry matter degradation $\left(\mathrm{R}^{2}=0.61\right.$, at $5 \%$ probability).

The addition of extract promoted a quadratic effect on the production of $\mathrm{CO}_{2} \mathrm{~g}^{-1}$ both of incubated and of degraded dry matter at 12 and 24 hours (Table 4). These results can be explained by the composition of the extract that presented a non-fibrous carbohydrate ratio of $39.92 \%$, characterizing it as a fast fermentation substrate, which may have contributed to the increase of the in vitro production of $\mathrm{CO}_{2}$. These results also corroborate those of Patra (2013), who found that the addition of a substrate rich in non-fibrous carbohydrates to the ruminal fluid resulted in higher $\mathrm{CO}_{2}$ production, with no change in $\mathrm{CH}_{4}$ production.

Methane production was affected by the addition of extract concentrations (75, 150, and $\left.250 \mathrm{~g} \mathrm{~L}^{-1}\right)$,

Pesq. agropec. bras., Brasília, v.53, n.4, p.504-513, Apr. 2018 DOI: 10.1590/S0100-204X2018000400012 
degradation time (12 and 24 hours), and the interaction between concentration and degradation time (Table 4). The addition of extract promoted a quadratic effect on the production of $\mathrm{CH}_{4} \mathrm{~g}^{-1}$ of incubated and of degraded dry matter at 12 and 24 hours. Forage-based diets tend to increase methane synthesis in the rumen due to higher hydrogen production, which is used by methanogenic archaea to produce methane (Knapp et al., 2014).

The extracts at the concentrations of 150 and 250 $\mathrm{g} \mathrm{L}^{-1}$ showed higher efficiency in the mitigation of
$\mathrm{CH}_{4}$ produced at 12 and 24 hours of incubation. Goel \& Makkar (2012) concluded that the decreased production of $\mathrm{CH}_{4}$ is related to the sensitivity of the methanogenic archaea to the decrease in $\mathrm{pH}$, reducing their activity. Methanogens are sensitive to different sources of lipids, such as fatty acids and oils, which makes lipid addition a viable strategy for the mitigation of $\mathrm{CH}_{4}$ production by ruminants. Maia et al. (2007) reported that forage grasses are sources of unsaturated fatty acids such as linoleic and linolenic acids, which

Table 4. Gas production, dry matter degradation (DMD), $\mathrm{pH}$ of ruminal fluid, production of carbon dioxide of the incubated dry matter of Urochloa brizantha $\left(\mathrm{CO}_{2} \mathrm{MLI}\right)$, production of $\mathrm{CO}_{2}$ of the degraded dry matter of U. brizantha $\left(\mathrm{CO}_{2} \mathrm{MLD}\right)$, methane of the incubated dry matter of $U$. brizantha $\left(\mathrm{CH}_{4} \mathrm{MLI}\right), \mathrm{CH}_{4}$ of the degraded dry matter of $U$. brizantha $\left(\mathrm{CH}_{4} \mathrm{MLD}\right)$, total production of short-chain fatty acids (SCFAs), acetic acid (HOAc), propionic acid (PPA), and butyric acid (BTA), according to the concentrations of the methanolic extract of Urochloa humidicola at 12 and 24 hours of incubation ${ }^{(1)}$.

\begin{tabular}{|c|c|c|c|c|c|c|c|c|c|c|c|c|}
\hline \multirow[t]{2}{*}{ Parameter } & \multirow[t]{2}{*}{$\mathrm{T}$ (hours) } & \multicolumn{4}{|c|}{ Concentration $\left(\mathrm{g} \mathrm{L}^{-1}\right)$} & \multirow[t]{2}{*}{ MSE } & \multirow{2}{*}{$\begin{array}{l}\mathrm{CV} \\
(\%)\end{array}$} & \multirow[t]{2}{*}{ Effect } & \multirow[t]{2}{*}{$\mathrm{R}^{2}$} & \multicolumn{3}{|c|}{ p-value } \\
\hline & & 0 & 75 & 150 & 250 & & & & & $\mathrm{C}$ & DT & CxDT \\
\hline \multirow{2}{*}{$\begin{array}{l}\text { Gas production } \\
(\mathrm{mL})\end{array}$} & 12 & 51.33 & 127.67 & 144.00 & 132.67 & 40.81 & 50.21 & Q & 0.87 & \multirow{2}{*}{$*$} & \multirow{2}{*}{$* *$} & \multirow{2}{*}{ ns } \\
\hline & 24 & 102.67 & 185.67 & 210.00 & 172.33 & 43.79 & 45.23 & $\mathrm{Q}$ & 0.85 & & & \\
\hline \multirow{2}{*}{$\begin{array}{l}\text { DMD } \\
(\%)\end{array}$} & 12 & 27.33 & 24.13 & 20.73 & 19.19 & 1.10 & 7.23 & $\mathrm{~L}$ & 0.88 & \multirow{2}{*}{$*$} & \multirow{2}{*}{ ns } & \multirow{2}{*}{$*$} \\
\hline & 24 & 41.02 & 32.73 & 25.19 & 25.72 & 1.45 & 8.46 & $\mathrm{~L}$ & 0.95 & & & \\
\hline \multirow{2}{*}{$\mathrm{pH}$} & 12 & 6.88 & 6.57 & 6.28 & 5.73 & 0.02 & 0.49 & $\mathrm{~L}$ & 0.88 & \multirow{2}{*}{$*$} & \multirow{2}{*}{$* *$} & \multirow{2}{*}{ ns } \\
\hline & 24 & 6.69 & 6.42 & 6.15 & 5.43 & 0.02 & 0.51 & $\mathrm{~L}$ & 0.89 & & & \\
\hline \multirow{2}{*}{$\begin{array}{l}\mathrm{CO}_{2} \mathrm{MLI} \\
\left(\mathrm{mL} \mathrm{g}^{-1}\right)\end{array}$} & 12 & 4.39 & 12.17 & 12.57 & 12.15 & 0.74 & 8.13 & Q & 0.84 & \multirow{2}{*}{$*$} & \multirow{2}{*}{ ns } & \multirow{2}{*}{$* * *$} \\
\hline & 24 & 9.56 & 24.77 & 25.19 & 25.67 & 0.94 & 7.63 & Q & 0.80 & & & \\
\hline \multirow{2}{*}{$\begin{array}{l}\mathrm{CO}_{2} \mathrm{MLD} \\
\left(\mathrm{mL} \mathrm{g}^{-1}\right)\end{array}$} & 12 & 16.37 & 50.55 & 61.14 & 63.68 & 14.09 & 37.40 & Q & 0.92 & \multirow{2}{*}{$*$} & \multirow{2}{*}{$\mathrm{ns}$} & \multirow{2}{*}{$*$} \\
\hline & 24 & 23.34 & 75.87 & 100.36 & 131.92 & 20.53 & 43.03 & Q & 0.91 & & & \\
\hline \multirow{2}{*}{$\begin{array}{l}\mathrm{CH}_{4} \mathrm{MLI} \\
\left(\mathrm{mL} \mathrm{g}^{-1}\right)\end{array}$} & 12 & 0.52 & 1.28 & 0.21 & 0.00 & 0.01 & 5.20 & Q & 0.32 & \multirow{2}{*}{$*$} & \multirow{2}{*}{$* *$} & ** \\
\hline & 24 & 2.00 & 4.69 & 0.92 & 0.02 & 0.02 & 2.05 & $\mathrm{Q}$ & 0.41 & & & \\
\hline $\mathrm{CH}_{4} \mathrm{MLD}$ & 12 & 1.93 & 5.50 & 1.02 & 0.06 & 0.14 & 6.41 & Q & 0.29 & $*$ & $* * *$ & $* * *$ \\
\hline$\left(\mathrm{mL} \mathrm{g}^{-1}\right)$ & 24 & 4.90 & 14.52 & 3.70 & 0.12 & 0.23 & 6.37 & $\mathrm{Q}$ & 0.41 & & & \\
\hline SCFA & 12 & 12.55 & 32.68 & 23.11 & 23.22 & 1.49 & 10.07 & Q & 0.39 & $*$ & $* * *$ & $\mathrm{~ns}$ \\
\hline$\left(\mu \mathrm{mol} \mathrm{mL} L^{-1}\right)$ & 24 & 18.45 & 42.55 & 26.79 & 25.44 & 1.77 & 10.85 & $\mathrm{Q}$ & 0.32 & & & IIS \\
\hline HOAc & 12 & 7.69 & 20.28 & 19.61 & 17.55 & 0.66 & 6.41 & Q & 0.81 & $*$ & ns & Se \\
\hline$\left(\mu \mathrm{mol} \mathrm{mL} L^{-1}\right)$ & 24 & 11.70 & 24.93 & 22.21 & 18.31 & 0.79 & 7.12 & $\mathrm{Q}$ & 0.45 & & IIS & $10 \mathrm{~S}$ \\
\hline PPA & 12 & 3.40 & 10.43 & - & 4.07 & 0.16 & 4.04 & Q & 0.89 & $*$ & $* * *$ & ns \\
\hline$(\mu \mathrm{mol} \mathrm{mL}-1)$ & 24 & 4.49 & 12.72 & - & 9.04 & 0.21 & 4.21 & Q & 0.82 & & & \\
\hline BTA & 12 & 1.46 & 5.44 & 3.50 & 1.60 & 0.04 & 2.33 & Q & 0.52 & $*$ & $n s$ & $\mathrm{~ns}_{\mathrm{s}}$ \\
\hline$\left(\mu \mathrm{mol} \mathrm{mL} L^{-1}\right)$ & 24 & 2.25 & 7.36 & 4.58 & 1.10 & 0.05 & 2.69 & $\mathrm{Q}$ & 0.63 & & IIS & ns \\
\hline
\end{tabular}

${ }^{(1)} \mathrm{T}$, incubation time (hours); MSE, mean standard error; CV, coefficient of variation; Effect, effect of linear (L) and quadratic (Q) regressions; $\mathrm{R}^{2}$, coefficient of determination; C, concentration $\left(\mathrm{g} \mathrm{L}^{-1}\right)$; DT, degradation time; and CxDT, interaction between concentration and degradation time. *,

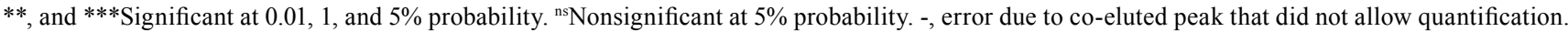


act on the cellulolytic microbiota, and that they favor the use of grass extracts as manipulators of ruminal fermentation.

Knapp et al. (2014) observed that increased ether extract content in the diet resulted in decreased $\mathrm{CH}_{4}$ production per unit of milk produced $(\mathrm{kg})$, according to lipid sources and content.

Wanapat et al. (2015) verified that unsaturated fatty acids added to ruminant diets reduced gas production due to their toxic effect on the ruminal protozoa that act on fiber digestion, as well as on methanogens, and to the competition generated when hydrogens are employed in the biohydrogenation process of the unsaturated lipid bonds instead of in $\mathrm{CH}_{4}$ production. Those authors also found that plant extracts can affect ruminal fermentation due to the presence of active secondary metabolites, such as saponins and tannins, which have an effect on methanogens and on the nutrient degradation of the diet.

The extract of $U$. humidicola at the concentrations of 150 and $250 \mathrm{~g} \mathrm{~L}^{-1}$ negatively affected the degradation of $U$. brizantha dry matter. The obtained results are in alignment with those obtained by Holtshausen et al. (2009), who observed a lower fermentation rate of the diet in the rumen with the reduction of $\mathrm{CH}_{4}$ production when using plant extracts containing secondary metabolites (saponins). Aguilar-Hernández et al. (2016) fed heifers a diet supplemented with Macleaya cordata R.Br. as a source of alkaloids and concluded that there was an improvement in the use of nitrogen compounds in the diet due to the activity of the alkaloids on the amino acid-fermenting bacteria.

The proportions of acetic acid and butyric acid produced during 12 and 24 hours of fermentation presented a quadratic effect. Suharti et al. (2011) found that the addition of the $S$. rarak extract did not affect the total SCFA production, but the concentration of 0.8 $\mathrm{mg} \mathrm{mL} \mathrm{m}^{-1}$ increased the propionic acid proportion and reduced the acetate:propionate ratio.

Therefore, the presence of non-fibrous carbohydrates, lipids, and secondary metabolites confers to the $U$. humidicola extract characteristics that allow its use as a rumen fermentation manipulator.

\section{Conclusions}

1. The methanolic extract of Urochloa humidicola has lipids and secondary metabolites that act together on ruminal parameters.

2 . The methanolic extract of $U$. humidicola reduces the production of gases from non-fibrous carbohydrates at the concentrations of 75,150 , and $250 \mathrm{~g} \mathrm{~L}^{-1}$, but it negatively affects the degradation of the dry matter of $U$. brizantha at the concentrations of 150 and $250 \mathrm{~g} \mathrm{~L}^{-1}$.

3. The methanolic extract reduces methane production and increases short-chain fatty acid production at the concentrations of 75,150 , and $250 \mathrm{~g} \mathrm{~L}^{-1}$.

\section{Acknowledgments}

To Conselho Nacional de Desenvolvimento Científico e Tecnológico (CNPq), to Coordenação de Aperfeiçoamento de Pessoal de Nível Superior (Capes), to Universidade Federal Rural do Rio de Janeiro (UFRRJ), to Fundação de Amparo à Pesquisa do Estado de Minas Gerais (Fapemig), and to the project Pecus-RumenGases of Empresa Brasileira de Pesquisa Agropecuária (Embrapa), for support.

\section{References}

AGUILAR-HERNÁNDEZ， J.A.; URÍAS-ESTRADA， J.D.; LÓPEZ-SOTO, M.A.; BARRERAS, A.; PLASCENCIA, A.; MONTAÑO, M.; GONZÁLEZ-VIZCARRA, V.M.; ESTRADAANGULO, A.; CASTRO-PÉREZ, B.I.; BARAJAS, R.; ROGGE, H.I.; ZINN, R.A. Evaluation of isoquinoline alkaloid supplementation levels on ruminal fermentation, characteristics of digestion, and microbial protein synthesis in steers fed a highenergy diet. Journal of Animal Science, v.94, p.267-274, 2016. DOI: $10.2527 /$ jas.2015-9376.

BRUM, K.B.; HARAGUCHI, M.; LEMOS, R.A.A.; RIETCORREA, F.M.; FIORAVANTI, M.C.S. Crystal-associated cholangiopathy in sheep grazing Brachiaria decumbens containing the saponin protodioscin. Pesquisa Veterinária Brasileira, v.27, p.39-42, 2007. DOI: 10.1590/S0100-736X2007000100007.

BUSTAMANTE, M.M.C.; NOBRE, C.A.; SMERALDI, R.; AGUIAR, A.P.D.; BARIONI, L.G.; FERREIRA, L.G.; LONGO, K.; MAY, P.; PINTO, A.S.; OMETTO, J.P.H.B. Estimating greenhouse gas emissions from cattle raising in Brazil. Climatic Change, v.115, p.559-577, 2012. DOI: 10.1007/s10584-012-0443-3.

CASTILLO-GONZÁLEZ, A.R.; BURROLA-BARRAZA, M.E.; DOMÍNGUEZ-VIVEROS, J.; CHÁVEZ-MARTÍNEZ, A. Rumen microorganisms and fermentation. Microorganismos $\mathrm{y}$ fermentación ruminal. Archivos de Medicina Veterinaria, v.46, p.349-361, 2014. DOI: 10.4067/S0301-732X2014000300003. 
DELGADO, D.C.; GALINDO, J.; GONZÁLEZ, R.; GONZÁLEZ, N.; SCULL, I.; DIHIGO, L.; CAIRO, J.; ALDAMA, A.I.; MOREIRA, O. Feeding of tropical trees and shrub foliages as a strategy to reduce ruminal methanogenesis: studies conducted in Cuba. Tropical Animal Health and Production, v.44, p.10971104, 2012. DOI: 10.1007/s11250-011-0045-5.

EL-WAZIRY, A.M. Nutritive value assessment of ensiling or mixing acacia and atriplex using in vitro gas production technique. Research Journal of Agriculture and Biological Sciences, v.3, p.605-614, 2007.

FRANCE, J.; DHANOA, M.S.; THEODOROU, M.K.; LISTER, S.J.; DAVIES, D.R.; ISAC, D. A model to interpret gas accumulation profiles with "in vitro" degradation of ruminant feeds. Journal of Theoretical Biology, v.163, p.99-111, 1993. DOI: 10.1006/jtbi.1993.1109.

GOEL, G.; MAKKAR, H.P.S. Methane mitigation from ruminants using tannins and saponins. Tropical Animal Health and Production, v.44, p.729-739, 2012. DOI: 10.1007/s11250-0119966-2.

GREATHEAD, H. Plants and plant extracts for improving animal productivity. Proceedings of the Nutrition Society, v.62, p.279290, 2003. DOI: 10.1079/PNS2002197.

GUIMARÃES JÚNIOR, R.; GONÇALVES, L.C.; JAYME, D.G.; PIRES, D.A. de A.; RODRIGUES, J.A. dos S.; TOMICH, T.R. Degradabilidade in situ de silagens de milheto em ovinos. Ciência Animal Brasileira, v.11, p.334-343, 2010. DOI: 10.5216/ cab.v11i2.7053.

HAO, H.; CHENG, G.; IQBAL, Z.; AI, X.; HUSSAIN, H.I.; HUANG, L.; DAI, M.; WANG, Y.; LIU, Z.; YUAN, Z. Benefits and risks of antimicrobial use in food-producing animals. Frontiers in Microbiology, v.5, 2014. DOI: 10.3389/fmicb.2014.00288.

HOLTSHAUSEN, L.; CHAVES, A.V.; BEAUCHEMIN, K.A.; MCGINN, S.M.; MCALLISTER, T.A.; ODONGO, N.E.; CHEEKE, P.R.; BENCHAAR, C. Feeding saponin-containing Yucca schidigera and Quillaja saponaria to decrease enteric methane production in dairy cows. Journal of Dairy Science, v.92, p.2809-2821, 2009. DOI: 10.3168/jds.2008-1843.

HORWITZ, W.; LATIMER JR., G.W. (Ed.). Official methods of analysis of AOAC International. 18th ed. Gaithersburg: AOAC International, 2005.

KHAN, N.A.; FAROOQ, M.W.; ALI, M.; SULEMAN, M.; AHMAD, N.; SULAIMAN, S.M.; CONE, J.W.; HENDRIKS, W.H. Effect of species and harvest maturity on the fatty acids profile of tropical forages. The Journal of Animal and Plant Sciences, v.25, p.739-746, 2015.

KIM, E.T.; KIM, C.-H.; MIN, K.-S.; LEE, S.S. Effects of plant extracts on microbial population, methane emission and ruminal fermentation characteristics in in vitro. Asian-Australasian Journal of Animal Sciences, v.25, p.806-811, 2012. DOI: 10.5713/ ajas.2011.11447.

KNAPP, J.R.; LAUR, G.L.; VADAS, P.A.; WEISS, W.P.; TRICARICO, J.M. Invited review: enteric methane in dairy cattle production: quantifying the opportunities and impact of reducing emissions. Journal of Dairy Science, v.97, p.3231-3261, 2014. DOI: $10.3168 /$ jds.2013-7234.

MAIA, M.R.G.; CHAUDHARY, L.C.; FIGUERES, L.; WALLACE, R.J. Metabolism of polyunsaturated fatty acids and their toxicity to the microflora of the rumen. Antonie van Leeuwenhoek, v.91, p.303-314, 2007. DOI: 10.1007/s10482-0069118-2.

MANIRAKIZA, P.A.; COVACI, A.; SCHEPENS, P. Comparative study on total lipid determination using Soxhlet, Roese-Gottlieb, Bligh \& Dyer, and modified Bligh \& Dyer extraction methods. Journal of Food Composition and Analysis, v.14, p.93-100, 2001. DOI: $10.1006 /$ jfca.2000.0972.

MATOS, F.J. de A. Introdução à fitoquímica experimental. $3^{\text {rd }}$ ed. Fortaleza: Edições UFC, 2009. 150p.

MAURICIO, R.M.; MOULD, F.L.; DHANOA, M.S.; OWEN, E.; CHANNA, K.S.; THEODOROU, M.K. A semi-automated in vitro gas production technique for ruminant feedstuff evaluation. Animal Feed Science and Technology, v.79, p.321-330, 1999. DOI: 10.1016/S0377-8401(99)00033-4.

MOULD, F.L.; ØRSKOV, E.R. Manipulation of rumen fluid $\mathrm{pH}$ and its influence on cellulolysis in sacco, dry matter degradation and the rumen microflora of sheep offered either hay or concentrate. Animal Feed Science and Technology, v.10, p.1-14, 1983. DOI: 10.1016/0377-8401(83)90002-0.

OLIVEIRA, D.R. de; NEPOMUCENO, D.D.; CASTRO, R.N.; BRAZ FILHO, R.; CARVALHO, M.G. de. Special metabolites isolated from Urochloa humidicola (Poaceae). Anais da Academia Brasileira de Ciências, v.89, p.789-797, 2017. DOI: 10.1590/0001-3765201720160126.

PATRA, A.K. The effect of dietary fats on methane emissions, and its other effects on digestibility, rumen fermentation and lactation performance in cattle: a meta-analysis. Livestock Science, v.155, p.244-254, 2013. DOI: 10.1016/j.livsci.2013.05.023.

SAEG: sistema para análises estatísticas. Versão 9.1. Viçosa: Fundação Arthur Bernardes, UFV, 2007. 150p.

SANTOS, H.G. dos; JACOMINE, P.K.T.; ANJOS, L.H.C. dos; OLIVEIRA, V.A. de; OLIVEIRA, J.B. de; COELHO, M.R.; LUMBRERAS, J.F.; CUNHA, T.J.F. (Ed.). Sistema brasileiro de classificação de solos. 2.ed. Rio de Janeiro: Embrapa Solos, 2006. 306p.

SEO, S.; LEE, S.C.; LEE, S.Y.; SEO, J.G.; HA, J.K. Degradation kinetics of carbohydrate fractions of ruminant feeds using automated gas production technique. Asian-Australasian Journal of Animal Sciences, v.22, p.356-364, 2009. DOI: 10.5713/ajas.2009.80613.

SUHARTI, S.; ASTUTI, D.A.; WINA, E.; TOHARMAT, T. Rumen microbial population in the in vitro fermentation of different ratios of forage and concentrate in the presence of whole lerak (Sapindus rarak) fruit extract. Asian-Australasian Journal of Animal Sciences, v.24, p.1086-1091, 2011. DOI: 10.5713/ ajas.2011.10409. 
TADESSE, G. Rumen manipulation for enhanced feed utilization and improved productivity performance of ruminants: a review. Momona Ethiopian Journal of Science, v.6, p.3-17, 2014.

VAKILI, A.R.; KHORRAMI, B.; MESGARAN, M.D.; PARAND, E. The effects of thyme and cinnamon essential oils on performance, rumen fermentation and blood metabolites in Holstein calves consuming high concentrate diet. AsianAustralasian Journal of Animal Sciences, v.26, p.935-944, 2013. DOI: 10.5713/ajas.2012.12636.
WANAPAT, M.; CHERDTHONG, A.; PHESATCHA, K.; KANG, S. Dietary sources and their effects on animal production and environmental sustainability. Animal Nutrition, v.1, p.96103, 2015. DOI: 10.1016/j.aninu.2015.07.004.

WINA, E.; MUETZEL, S.; BECKER, K. The impact of saponins or saponin-containing plant materials on ruminant productions: a review. Journal of Agricultural and Food Chemistry, v.53, p.8093-8105, 2005. DOI: 10.1021/jf048053d.

Received on January 30, 2017 and accepted on July 26, 2017 